\title{
Myślenie krytyczne w ujęciu psychopedagogicznym - w kierunku poznawczej samodzielności i odpowiedzialności jednostki
}

\author{
Iwona CZAJA-CHUDYBA*
}

\begin{abstract}
Critical thinking in terms of psycho-pedagogy: towards individual cognitive independence and responsibility: The paper is devoted to the methods of recognition and development of critical thinking. In the initial part synthetically are presented the views of researchers connected with an education perspective (the definition and features of critical thinking). Within this aspect crucial appears the question: why are we afraid of criticism? What are the reasons why we do not apply it in contact with the cultural message, with the opinions and actions of people? For relatively seldom is it used as a support in discussion, in making decisions and choices. In an attempt to answer such formulated problems presented is an outline of the author's classification for inhibitors that prevent or hinder the application of critical thinking. Here the main claim is that in the modern world of news excess and the chaos of values, critical thinking as a manifestation of cognitive self-reliance and responsibility should become the competence characterizing each individual. Hence, the author formulates some recommendations concerning pedagogical practice. They are implied from the author's concept of constructive criticism, the adopted the principles and methods supporting critical thinking.
\end{abstract}

\section{KEYWORDS}

constructive criticism; barriers to critical thinking; fostering constructive criticism

* Dr hab., prof. UP, Instytut Pedagogiki Przedszkolnej i Szkolnej, Uniwersytet Pedagogiczny im. KEN w Krakowie. E-mail: iwona.czaja-chudyba@up.krakow.pl. 
Dlaczego tak wielu edukatorów jest przekonanych, że krytyczne myślenie to klucz do reformy edukacji? Odpowiedź w dużej mierze sprowadza się do tego, że chcemy, żeby uczniowie umieli więcej, niż po prostu myśleć - równie ważne jest, by posługiwali się dobrym sądem (Lipman, 2003: 226; przet. Anna Łagodzka).

\section{WPROWADZENIE}

Przemiany współczesności - cywilizacji nadmiaru informacji i chaosu wartości - wymagają od nas większej uważności i myślenia krytycznego. Dlatego ważne są pytania o sposoby ujmowania i rozwijania myślenia krytycznego, a także o przyczyny jego nieobecności w edukacji. Cel ten implikuje wskazanie personalnych i zewnątrzpochodnych powodów rzadkiego wykorzystywania krytycznej refleksji w selekcji informacji i nabywaniu wiedzy, uniemożliwiających lub utrudniających stosowanie myślenia krytycznego w dyskusjach, podejmowaniu decyzji i dokonywaniu wyborów.

Poniższe refleksje nad inhibitorami myślenia krytycznego stanowią wynik wieloletniego zainteresowania i badawczego opracowania tej problematyki na gruncie psychologii i pedagogiki; zaowocowały one próbą systematyzacji barier oraz sprecyzowania własnej koncepcji konstruktywnego krytycyzmu jako odrębnej formy myślenia, łączącej elementy myślenia twórczego i logiczno-analitycznego.

Swiadomość tego, jakie są przyczyny unikania krytyki, wydaje się odgrywać niebagatelną rolę $\mathrm{w}$ wielu zagadnieniach psychopedagogicznych, takich jak: krytyka w sytuacji facylitacji społecznej; myślenie, działanie i komunikowanie w sytuacji oceny, presji, stresu; krytyka rozumiana jako inhibitor vs. impuls do twórczości; krytyka w odniesieniu do autorytetu, wzorów i stylów wychowawczych; funkcjonowanie krytyki w kulturze i środowisku szkoły; habitus nauczyciela — jego reakcje w sytuacji krytyki, samodzielności i niezależności; nauczycielskie przedzałożenia dotyczące „krytycznego” ucznia. Przede wszystkim jednak świadomość ta może stanowić podstawę doskonalenia praktyki pedagogicznej, wspierania ucznia i nauczyciela w samorozwoju.

Prowadzone od szeregu lat badania empiryczne, a także teoretyczne analizy perspektyw definiowania tego konstruktu w ramach pedagogiki (Czaja-Chudyba, 2013a; Czaja-Chudyba, 2013c; Czaja-Chudyba, 2017; Czaja-Chudyba, 2020) po pierwsze - uprawniają do sformułowania tezy o braku jednolitego definiowania i rozumienia krytycyzmu, po drugie - wzmacniają zasadność wskazania, iż w procesie minimalizacji barier decydujące jest założenie o konstruktywnym wymiarze krytyki. Z psychologicznego punktu widzenia - tylko taki krytycyzm wydaje się do zaakceptowania dla podmiotów, uczestniczących w procesie edukacji i z tak rozumianym krytycyzmem można 
konfrontować oraz oswajać w programie abarietycznego rozwijania myślenia krytycznego (którego kwintesencję zamieszczono na koniec artykułu w formie rekomendacji pedagogicznych).

\section{W OBLICZU NIEJEDNORODNOŚCI ROZUMIENIA POJECCIA KRYTYCYZMU}

Podejmując próbę określenia, czym jest myślenie krytyczne oraz jakie są jego wymiary i typy, należy zwrócić uwagę na trzy zagadnienia - heterogeniczności definiowania, niewielkiej reprezentatywności tego pojęcia dla analiz/badań psychologicznych oraz różnorodności występowania form krytycyzmu. Istotna jest też konstatacja, iż pedagogiczne rozważania o istocie myślenia krytycznego prowadzone są najczęściej przez filozofów - badaczy procesów edukacyjnych.

Mnogość znaczeń przypisywanych pojęciu krytycyzmu może powodować trudności w jego pojmowaniu i interpretowaniu. Samo rozumienie myślenia krytycznego uznać można za niejednorodne i nie w pełni doprecyzowane. Krytycyzm może być ujmowany jako strategia lub sposób rozumowania, obejmujące: umiejętności bezstronnego, refleksyjnego, racjonalnego, analitycznego osądu, albo jako postawa lub system pedagogiczny, gdy nacisk położony jest na funkcję, jaką może pełnić myślenie krytyczne w życiu jednostki czy społeczeństwa. Różnicę pomiędzy oboma podejściami rozpatrywania krytycyzmu opisuje Peter McLaren, stwierdzając, że badacze:

często mylą pojęcie «pedagogiki krytycznej» z pojęciem «myślenia krytycznego». [...] myślenie krytyczne w tym przypadku odnosi się do rozwoju umiejętności poznawczych w celu rozwiązywania coraz bardziej złożonych problemów intelektualnych (McLaren, 1991: 43).

Prekursorskie dla pierwszej perspektywy wydaje się stanowisko Johna Deweya, który założył, że warunkiem myślenia refleksyjnego jest stan wątpienia i prowadzenie systematycznych badań, a także że wiąże się ono z potrzebą analizy różnorodnych argumentów, odpowiedzialnością oraz szczerością. Autor łączył z tym myśleniem także stan niepewności oraz akt „zawieszenia sądu” (Dewey, 1988: 14). Tradycyjnie krytycyzm bywa też utożsamiany z racjonalnością, stąd Robert H. Ennis objaśnia go jako: „racjonalne, refleksyjne myślenie, skupiające się na decydowaniu, w co wierzyć i co robić” (Ennis, 2003: 295; przet. I.Cz-Ch.). Często dodatkowo wzbogaca się tę definicję precyzacją cech/standardów rozumowania, które stanowią o jego jakości i specyfice. Dla Richarda W. Paula (Paul, 1996) w rozumowaniu tego typu istotne jest narzucanie sobie standardów: prawidłowego analizowania, syntetyzowania i oceniania informacji uzyskanych z obserwacji, doświadczeń, wnioskowania, 
komunikowania. Standardy dla tak ujmowanego myślenia krytycznego obejmują: jasność (klarowność), precyzyjność, ścisłossć, dokładność, trafność, konkretność, spójność, logiczność, głębokość, wnikliwość, kompletność, ważność, istotność, adekwatność w stosunku do tematu i bezstronność (Paul, 1996; Paul $\&$ Elder, 2005). Kryteria te należą do wartościowych charakterystyk racjonalnego sposobu postępowania, a uczenie ich rozpoznawania i stosowania jest istotnym wymiarem uczenia krytycznego myślenia.

$\mathrm{Za}$ doskonałą egzemplifikację owego opisowego podejścia w odniesieniu do uściślenia natury krytycyzmu mogą służyć też propozycje Diane Halpern (Halpern, 2003a; Halpern, 2003b), która zestawia aż trzydzieści cztery szczegółowe zdolności, grupując je w pięciu zakresach (umiejętności werbalnych, umiejętności analitycznych, testowania hipotez, wykorzystania niepewności i prawdopodobieństw oraz podejmowania decyzji i rozwiązywania problemów). Próbę bardziej syntetycznego i holistycznego objaśnienia podjął Matthew Lipman (Lipman, 1996; Lipman, 2003), precyzując, że myślenie krytyczne, obejmuje umiejętności o charakterze umysłowym (związane z kryterium poznawczej odpowiedzialności, obiektywności, użyteczności oraz logiczności). Dla autora łączy się ono z wydawaniem przemyślanych sądów, samokorygowaniem i wrażliwością na kontekst (Lipman, 2003: 217-218). Równocześnie, krytycznie analizując klasyczną definicję Ennisa, Lipman zauważa, iż jest ono raczej skierowane na sceptyczne wyznaczenie „W co nie wierzyć i czego nie robić” (Lipman, 2003: 214).

Z kolei postawa krytyczna czy, jak ją określa Paul, „duch krytycyzmu”, wiąże się z interpretacją rzeczywistości społecznej i wyraża się niezgodą na nierówność oraz niesprawiedliwość (będącą wynikiem sprzeczności interesów jednostki i dominujących praktyk społecznych, władzy, wiedzy i kultury). Krytyczna refleksja w tym rozumieniu wspiera wyzwolenie, emancypację i transformację (ową optykę przyjmowali przedstawiciele teorii antyau torytarnych, krytycznych, spopularyzowanych przez szkołę frankfurcką, łączoną z Theodorem Adorno, Maxem Horkheimerem, Erichem Frommem, Herbertem Marcusem oraz później z rozważaniami między innymi Jürgena Habermasa, Henry'ego Girouxa, Petera McLarena, Paula Freire’a). Centralną kategorią jest tu imperatyw wolności i autonomii jednostki, krytyczna refleksja ewokuje obronę przeciw totalitaryzmowi i uprzedmiotowieniu, a myślenie krytyczne wykorzystuje się najczęściej w celu destrukcji - burzenia utartych reguł, struktur lub nawyków myślenia (por. pedagogika oporu). W pedagogice emancypacyjnej myślenie krytyczne pojawia się w nieco bardziej transgresyjnym charakterze - jako forma poznawczej samodzielności, pozwalająca na zdobywanie nowych możliwości, kreowanie aspiracji i dostrzeganie życiowych szans. Dla polskiej badaczki Marii Czerepaniak-Walczak świadomość krytyczna wyraża się zauważaniem ograniczeń i deprywacji, jakim podlega jednostka, wybieraniem sposobów ich usuwania i osiąganiem „nowych praw i pól wolności” (Czerepaniak-Walczak, 1995: 138). Podobnie krytykę 
wyjaśniał Robert Kwaśnica (Kwaśnica, 1990: 117), według którego umożliwia ona ocenę własnych możliwości i ograniczeń, własnej zależności od nierewidowanych przeświadczeń, przedzałożeń, a dzięki której dąży się do „zrozumienia uwarunkowań i sposobu kształtowania się symbolicznej reprezentacji świata, struktury sensu" (Kwaśnica, 2007: 75). Według tego autora krytyka jest osiąganiem samowiedzy, postawą czujności wobec iluzji (Kwaśnica, 1990: 117).

Próbując wskazać na ważność zarówno poznawczych, jak i osobowych kompetencji Ennis (Ennis, 2001; Ennis, 2003) odróżnił umiejętności (analizy założeń, oceny wiarygodności źródeł, identyfikowania stanowisk i podejść, tworzenia i redefiniowania pytań) od postaw, nazywanych dyspozycjami (nastawienie pytajne, uważność na podstawy sądów i twierdzeń, uwzględnianie maksymalnie wielu uwarunkowań i kontekstów, potrzeba bycia dobrze poinformowanym oraz powstrzymywania się od osądu, gdy dowody wydają się niewystarczające). Tę dwoistość eksplikacji krytycyzmu (jako procedury i postawy) dobrze oddaje także myśl Ewy Wasilewskiej-Kamińskiej, iż myślenie krytyczne „jednocześnie kultywuje [...] intelektualny rygor badawczy i refleksję, dyscyplinę intelektualną i intelektualną autonomię" (Wasilewska-Kamińska, 2016: 77). Podobną próbę zbliżenia i inkluzji powyższych perspektyw można odnaleźć też w koncepcji myślenia krytycznego jako ideału edukacyjnego Harveya Siegela. Opisując go, autor konkluduje:

Ta dwuelementowa koncepcja [...] — według której myślenie krytyczne obejmuje zarówno element oceny racji, jak i element ducha krytycznego, związany z dyspozycjami - jest aprobowana przez większość teoretyków (Siegel, 2019: 103).

Odnosząc się do charakterystyki myślenia krytycznego w obszarze dociekań psychologicznych, należy zauważyć istotny brak zainteresowania i analiz $\mathrm{z}$ tej perspektywy. Interesującym tropem analiz psychopedagogicznych - ale prowadzonych najczęściej przez filozofów (Matthews, 1996; Lipman, 2003) jest problem dojrzałości vs. niedojrzałości umysłowej i emocjonalnej dzieci do podejmowania refleksji krytycznej. Jednak badaczy szerzej podejmujących temat myślenia krytycznego jest niewielu — do nielicznych zaliczyć można Diane Halpern (Halpern, 2003a; Halpern, 2003b), a z polskich psychologów - Edwarda Nęckę, Jarosława Orzechowskiego i Błażeja Szymurę (Nęcka, Orzechowski, \& Szymura, 2006: 428-429), którzy łączą ów rodzaj myślenia oraz refleksji z ewaluacją/oceną, realizmem, rzetelnością oraz z myśleniem specyficznym dla filozofii, a nawet religii ${ }^{1}$. Psychologowie często wyrażają pogląd o dysfunkcjonalności krytyki dla dobrostanu psychicznego jednostki, a także

\footnotetext{
${ }^{1}$ Niedostatek zainteresowania psychologów opisem myślenia krytycznego dobrze obrazuje całkowity brak opisu tego konstruktu w klasycznym, poświęconym procesom poznawczym, podręczniku akademickim Tomasza Maruszewskiego (Matuszewski, 2001), który — za Nęcką — wymienia jedynie nazwę tej operacji intelektualnej, całkowicie pomijając jej charakterystykę.
} 
przeciwstawiają często krytycyzm twórczości, uznając go za jeden z jej inhibitorów (Nęcka et al., 2008). Wspólna dla filozofii, psychologii i pedagogiki wydaje się więc perspektywa rozumienia ontologicznego statusu krytycznego myślenia jako racjonalnego, związanego z poznawczą autonomią i odpowiedzialnością.

\section{RODZAJE KRYTYCYZMU}

W klasycznej już koncepcji Paul (Paul, 1996) wyróżnił „słabą” i „mocną” formę myślenia krytycznego. Pierwsza — samooszukiwanie się (self-deception) — jest związana z wykorzystaniem elementarnych zdolności krytycznego myślenia do własnych, często egocentrycznych (obrony własnych racji, deprecjonowania innych) celów. Mocny sens myślenia krytycznego zaznacza się w jego bezstronności oraz w stosowaniu go w służbie obiektywnej, „wyważonej prawdy”, racjonalności, autonomii i samoświadomości. Jednak analiza współczesnych kontekstów krytycyzmu pozwala na wyłonienie „trzeciej drogi” — związanej z połączeniem myślenia krytycznego i twórczości. Można więc założyć istnienie formy krytyki: 1) negatywnej, destruktywnej, 2) obiektywnej, neutralnej oraz 3) konstruktywnej, pozytywnej.

W moim przekonaniu konstruktywny krytycyzm (Czaja-Chudyba, 2013b) jest zatem typem racjonalnego myślenia, skierowanego na nadawanie wartości i redukowanie braków. W podejściu tym podkreśla się twórczy sens krytyki poprzez znaczenie słowa „konstruktywny” - czyli budujący, ulepszający, dodający. Myślenie konstruktywnie krytyczne to typ rozumowania, w którym nie tyle burzymy, co czynimy krok do przodu - samodzielnie konstruujemy wiedzę, poprzez dostrzeganie jej luk, braków, nieścisłości. Dzięki wykorzystaniu konstruktywnej krytyki nie niszczymy rzeczywistości, ale ją ulepszamy i modyfikujemy. Konstruktywne myślenie krytyczne odróżnia się od innych rodzajów krytycyzmu tym, że opiera się ono nie tylko na kryteriach logiczności, ale i na użyteczności. Za Halpern (Halpern, 2003a; Halpern, 2003b) można je nazwać „dobrym” myśleniem. Pozostaje w opozycji do krytykanctwa, czyli skupiania się jedynie na negatywnych stronach rzeczywistości. Łączy się z poznawczą odpowiedzialnością (Dennet, 2017: 534), rozumianą jako poczucie obowiązku przedstawienia uzasadnień dla prezentowanych przekonań, „uprzejmą nieufnością" wobec rzeczywistości oraz próbą jej udoskonalania.

\section{DLACZEGO BOIMY SIE KRYTYKI? ZARYS KLASYFIKACJI INHIBITORÓW KRYTYCZNEGO MYŚLENIA}

Choć postulat upowszechnienia konstruktywnego myślenia krytycznego wydaje się koniecznością, szczególnie w obszarze działań związanych z edukacją 
i samorozwojem jednostki, jednak należy stwierdzić, iż we współczesnym świecie idea ta nadal pozostaje w sferze życzeń. Dlatego wydaje się, że zasadne jest przyjrzenie się możliwym inhibitorom krytyki oraz wstępna systematyzacja owych barier według kryterium ich źródeł (por. schemat nr 1). Poniższa analiza uwarunkowań nieobecności krytycyzmu wynika z moich wieloletnich badań prowadzonych z perspektywy psychologa i pedagoga w grupach studentów, nauczycieli i uczniów szkół podstawowych (Czaja-Chudyba, 2013a; Czaja-Chudyba, 2013c; Czaja-Chudyba \& Muchacka, 2016)².

Schemat nr 1. Rodzaje barier myślenia krytycznego

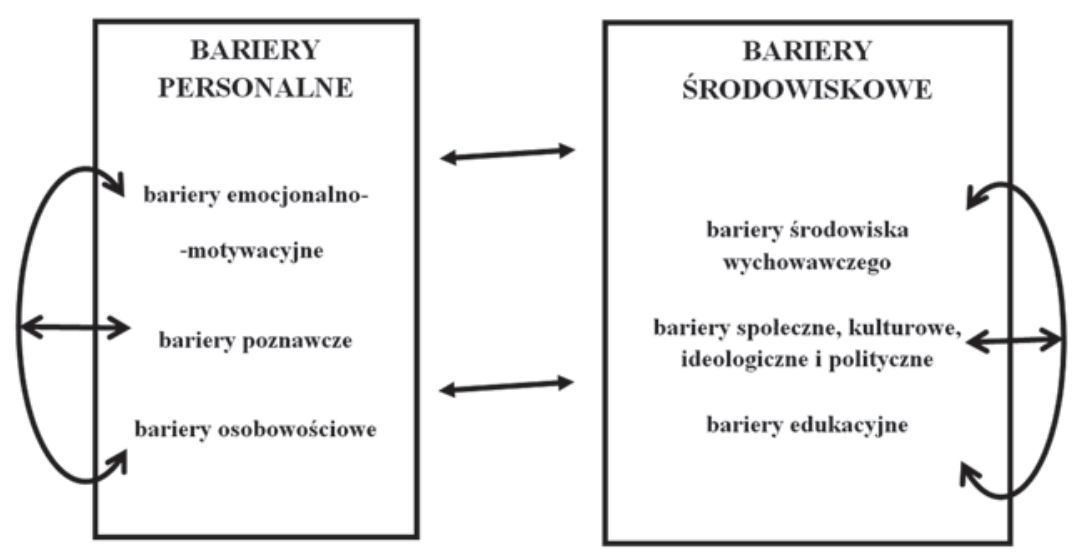

Źródło: opracowanie własne.

\section{BARIERY PERSONALNE}

Wśród przyczyn związanych z podmiotowymi predyspozycjami myślenia krytycznego należy podkreślić negatywną rolę barier: emocjonalno-motywacyjnych, poznawczych oraz osobowościowych.

Bariery emocjonalno-motywacyjne

Są udziałem osób niezaangażowanych poznawczo bądź też ujawniających silne stany lękowe przed krytyką jako sytuacją nową, nieznaną lub zagrażającą. Obejmują czynniki hamujące procesy „zasilające” krytykę oraz te, których podstawą są negatywne uczucia, łączone z krytyką, między innymi lęk, wstyd lub

${ }^{2}$ Rdzeń przedstawionej klasyfikacji jest efektem projektu badawczego (w tym empirycznych badań, prowadzonych w grupie 768 osób dorosłych i 379 dzieci), którego szczegółowa metodologia została opisana w pracy Myślenie krytyczne w kontekstach edukacji wczesnoszkolnej-uwarunkowania nieobecności (Czaja-Chudyba, 2013c). 
poczucie winy, a więc emocje skierowane na ochronę siebie lub innych. Ich częstym źródłem może być zaburzona samoocena, niska pozycja krytyki w hierarchii wartości, konflikt moralny lub poziom rozwoju moralnego ${ }^{3}$. Do najczęstszych motywów niepodejmowania krytyki należą:

- lęk przed karą lub utratą statusu

Motyw częsty u osób o niskiej samoocenie lub niestabilnej pozycji w grupie. Obawa przed utratą przywilejów pojawia się też nierzadko jako efekt uprzednich doświadczeń jednostek uwikłanych w silnie zhierarchizowane relacje.

- lęk przed porażką - poczucie wstydu

U podstaw działań człowieka leżą dwie główne motywacje: skuteczne wywieranie wpływu na bieg zdarzeń i ochrona poczucia własnej wartości („ochrona ja”). W tej perspektywie ograniczeniem krytyki jest strach przed kompromitacją, porażką, obnażeniem swojej niewiedzy, niekompetencji. Stanowi on skuteczną barierę szczególnie wtedy, gdy poziom aspiracji osoby jest za wysoki lub gdy jej samoocena jest zbyt niska.

- lęk przed utratą poczucia wspólnoty - poczucie winy z powodu zranienia kogoś

Ważnym powodem aktywności jednostki jest gwarantowanie sobie bezpieczeństwa: w wymiarze poznawczym (poprzez powielanie wzorów i regut) oraz emocjonalnym (poprzez przynależność do grupy; współdzielenie idei lub wartości oraz poprzez satysfakcjonujące więzi i kooperację z innymi, ich akceptację i szacunek). Bezpieczeństwo we wspólnocie jest podtrzymywane przez hermetyczną konsolidację wewnątrzgrupową i odróżnianie się od innych grup (na przykład podział na „nas” i „ich”). Krytyka wiąże się w tym wypadku z zaburzeniem relacji oraz z zagrożeniem dla utrzymania grupowej spójności, stabilności i zgody, dlatego często konfrontuje osobę z dylematem wyboru pomiędzy wspólnotą a indywidualnością/autonomią („Czy moja grupa ma rację?”). Ryzyko podejmowania krytyki wiąże się bowiem z powszechnym mniemaniem, że ma ona destruktywne konsekwencje (na przykład może wyrządzić komuś krzywdę).

${ }^{3}$ Problematyka moralnych i etycznych źródeł inhibitorów krytycznego myślenia, wartości vs. antywartości krytyki w edukacji, a także relacji „krytyka - moralnośc” wydaje się niezmiernie ważnym zagadnieniem z punktu widzenia analiz filozoficznych i edukacyjnych. Bariery mogą wynikać z poziomu rozwoju moralnego dziecka (o poziomach rozwoju moralnego por. np. Piaget, 1967; Modgil \& Modgil, 1986; Kohlberg \& Mayer, 1990; Socha, 2000); mogą pojawiać się w konsekwencji konfliktu etycznego; mogą mieć też korzenie w hierarchii wartości czy światopoglądzie jednostki oraz być odbiciem procesów socjalizacji, inkulturacji i narzuconych norm środowiskowych. Zagadnienie to zostało już opisane w moich poprzednich opracowaniach (Czaja-Chudyba, 2013a; Czaja-Chudyba, 2013b; Czaja-Chudyba, 2017; Czaja-Chudyba \& Muchacka, 2016). 
- lęk przed nowością

Krytyka wytrąca z komfortowego dla większości jednostek stanu, w którym wiedzą, co myśleć i jak się zachować. Najczęściej uświadamia coś nieoczekiwanego. W konfrontacji z nowością wiele osób odczuwa niepokój i zakłopotanie, a także lęk lub ambiwalencję podczas zderzenia „oswojonej” wiedzy z nieznanym czy niepewnym.

- lęk przed utratą niewinności i iluzji sprawiedliwego świata Niekwestionowana pewność opisu rzeczywistości i bezkrytyczny idealizm dają większości osób poczucie porządku otaczającego świata. Ujawnienie błędów weryfikuje trafność teorii wyjaśniających, może też doprowadzić jednostkę do kryzysu wiary w „sprawiedliwy świat”, w dobro drugiego człowieka, w pozytywne pobudki kształtujące społeczną, ekonomiczną i polityczną rzeczywistość (altruizm, szlachetność, humanitaryzm). Dlatego obawa przed utratą złudzeń, porzuceniem swoistej „niewinności” (Brookfield, 1995) oraz utopijności i naiwności może hamować krytykę.

- trudności z dostrzeganiem problemów i pytań Przeszkodę w ich formułowaniu może stanowić poznawcza ignorancja, posłuszeństwo (lęk przed podważeniem autorytetu) oraz wadliwie rozumiana norma grzeczności. Potocznie pytania utożsamiane bywają także z niewiedzą, a nie $z$ chęcią jej pogłębienia. Hamująco wpływa też brak odwagi - wrodzona nieśmiałość, wstyd, brak dociekliwości i wnikliwości oraz absolutyzowanie wiedzy - złudzenie jej oczywistości i pewności. Destruktywnie działa również przyjęcie postawy „lepiej się nie narażac’", uwidaczniające oportunizm lub konformizm (wyrażany przez dość powszechną potoczną normę „nie wychylaj się”).

- brak pasji, niechęć do wysiłku i zaangażowania Czynnikiem hamującym postawę krytyczną jest obojętność, niechęć do wysiłku, bierność i unikanie odpowiedzialności, tendencja do pozorowania działań. Łączy się także z pasywnością w sferze rozwoju osobistego - z brakiem pasji i autentycznego zaangażowania.

- konflikt motywów, celów i wartości

Obciążenie i chęć sprostania wielu zadaniom narzucanym jednostce przez otoczenie to częste przyczyny niechęci do krytycznego podejmowania tematów trudnych, nieoczywistych, wymagających refleksyjnego zastanowienia. Negatywnie działa więc: niska pozycja krytyki w hierarchii wartości jednostki, presja czasu, natłok informacji oraz zajęć i aktywności - często bardziej atrakcyjnych, podejmowanych w przestrzeni popkulturowych doznań. 
Jednym z podstawowych inhibitorów rozumowania krytycznego będzie niekompetencja poznawcza, powiązana z ogólnym poziomem intelektualnym jednostki i jakością edukacji. Bariera ta wyrażać się może jako pasywny sposób zdobywania wiedzy, ignorancja lub fundamentalizm:

- niewiedza, ignorancja i niska kultura poznawcza

Niezmiernie szkodliwe dla edukacji krytycznej są współczesne mity o łatwości i szybkości zdobywania wykształcenia, dewaluujące jego prawdziwy sens i naturę. Ignorancja i wynikająca z niedostatecznego, „pozornego” wykształcenia nonszalancja tworzą podstawy do odczuwania bezradności oraz niedowartościowania intelektualnego, swoistego „deficytu kompetencyjnego”. Niewielkie aspiracje w zakresie samodoskonalenia, słaby udział w życiu kulturalnym i mała samodzielność myślenia bywają maskowane arogancką manierą celowego antyintelektualizmu — niedoceniania (a często wyśmiewania) ambicji innych. Z drugiej strony - niskie kwalifikacje lub niewystarczająca wiedza skutkują poczuciem bycia nieuprawnionym do podejmowania krytyki „uzurpatorem”.

- niekompetencja językowa

Myślenie bezkrytyczne odzwierciedla się w języku i wyraża stosowaniem nawykowych, bezrefleksyjnie stosowanych kategorii, nieporadności i ograniczonego zasobu leksykalnego. Bardzo często łączy się także z nieumiejętnością przekazania swoich myśli w sposób jasny i precyzyjny, a także z dosłownością przekazu, ubóstwem znaczeń (Klus-Stańska, 2002).

- iluzja oczywistości

Efektem owej iluzji jest redukcja sprzeczności oraz dążenie do jasności i nieproblematyczności wiedzy, która umożliwia szybkie, automatyczne działanie oraz przekonanie, że na wszystkie pytania są gotowe odpowiedzi. Sprawia, że nie mamy nawyku pytania i sprawdzania danych. Kazimierz Obuchowski (Obuchowski, 1993: 68) łączy ją z „naiwnym realizmem”, czyli przekonaniem, że zdarzenia są takimi, jakie są. Może być też wynikiem obronności percepcyjnej (polegającej na niedopuszczeniu do świadomości treści niezgodnych z oczekiwaniami/przekonaniami lub im zagrażających), a zarazem sztywności percepcyjnej - tendencji do podtrzymywania tych poglądów, które w świetle nowych danych winny ulec zmianie.

- potrzeba upraszczania i domknięcia

Nasz umysł ma tendencje do nadawania organizacji nawet pozornie chaotycznym i rozproszonym informacjom, a także do upraszczania, gdy system 
poznawczy nie może sobie poradzić z nadmiarem danych. Stąd dążenie do jednoznacznych rozwiązań, zapewniającej poczucie przewidywalności, a unikanie wieloznaczności łączącej się z krytyczną refleksją. Najbardziej charakterystycznymi inhibitorami będą stereotypy - trwałe przedzałożenia oraz uproszczone schematy reprezentacji rzeczywistości, zakorzenione $\mathrm{w}$ procesach socjalizacji i inkulturacji, ekonomizujące nasze poznanie. Pozostając poza kontrolą świadomości, sprawiają, że jednostka nie ma do nich krytycznego dystansu.

- algorytmizacja i sztywność myślenia

Powstają wtedy, gdy utrwalone zostaną stałe style rozwiązywania problemów. Wykorzystywanie ich w sposób automatyczny i bezrefleksyjny nasila niechęć wobec alternatywnych strategii postępowania czy myślenia; często wspiera się uzasadnieniem, że „zawsze to działało, po co mam coś zmieniać?”.

- fundamentalizm interpretacyjny

Jego źródłem jest przekonanie o niepodważalności własnego (lub grupowego) punktu widzenia, posiadaniu jedynej racji; a w konsekwencji - uznawanie opinii niezgodnych z własnymi za wrogie lub dewiacyjne. Przejawia się także w nadreprezentacji strategii konfirmacyjnej, potwierdzającej własne sądy i w związku w tym tendencji do atakowania lub wykluczania myślących inaczej. Podtrzymują ją liczne zabiegi, między innymi przeinaczanie niewygodnych dla siebie argumentów, operowanie uproszczeniami, wykorzystywanie skrajnie emotywnych wyrażeń i symboli.

- negatywne konotacje związane z krytyką

Wynikają z przyjęcia potocznego rozumienia natury i istoty krytycyzmu, najczęściej przez pryzmat destruktywnego krytykanctwa.

\section{Bariery osobowościowe}

Cechy i względnie utrwalone wzorce zachowań, które manifestujemy, moga także determinować nasze postawy wobec krytyki. Najczęściej jest to:

- brak odwagi - niechęć do podjęcia ryzyka Inhibitorem postawy krytycznej jest asekuranctwo, nieśmiałość, wstydliwość, przekonanie o niskiej jakości i ważności swoich uzasadnień. Wyraża się ona też w niechęci do przezwyciężania własnych ograniczeń, małej odporności na stres, braku wiary w powodzenie własnych działań.

- bezrefleksyjność - automatyczność i impulsywność zachowań Najczęściej tworzą się w wyniku zaniżonego lub zawyżonego poziomu samoakceptacji, choć formę tych ograniczeń mogą kształtować też predyspozycje 
poznawcze i uwarunkowania środowiskowe (na przykład brak czasu, wadliwe standardy edukacyjne lub wzorce w rodzinie).

- egocentryzm i socjocentryzm

Pojawiają się jako efekt nadmiernie zawyżonej, bezrefleksyjnie podtrzymywanej samooceny osoby lub grupy i braku autokrytycznego dystansu. Manifestują się poprzez: niechęć do przyjęcia innych niż własne punktów widzenia, traktowanie własnej osoby/grupy jako centrum kontekstu społecznego, przecenianie własnej wartości i niedocenianie innych. Skutkiem bezkrytycznego socjocentryzmu jest skłonność do zafałszowań w interpretacji rzeczywistości - na przykład bezkrytyczne usprawiedliwianie i popieranie działań grupy, nawet jeśli okazały się one szkodliwe lub niemoralne.

- konformizm informacyjny i normatywny - naśladownictwo Czynnikiem wyzwalającym konformizm jest niepewność, potrzeba właściwego zachowywania się oraz naśladowania innych lub submisyjność i niska samoocena, chęć bycia akceptowanym, obawa przed odrzuceniem i izolacją społeczną. Łączą się też z pasywnością, indyferencją i niesamodzielnością poznawczą, a także niskim poziomem twórczości.

- autorytaryzm i dominacja

Chęć posiadania władzy nad innymi, a także postawa „posiadania monopolu na rację” jest charakterystyczna dla osób wykorzystujących krytykę destruktywną najczęściej do realizacji egoistycznych celów.

- niecierpliwość

Pośpiech, skrótowość i niecierpliwość są kluczowymi barierami dla krytycyzmu z pogranicza uwarunkowań charakterologiczno-środowiskowych, gdyż najczęściej to nasza niefrasobliwość i oczekiwanie natychmiastowej gratyfikacji działań hamują refleksję i dociekliwy namysł.

- konfliktowość

Cecha ta odróżnia krytykanctwo od postawy konstruktywnego krytycyzmu. Krytyka osób konfliktowych najczęściej jest negatywna, ma na celu sprowokowanie sprzeczki oraz „pokonania” przeciwnika. Takie jednostki zazwyczaj przejawiają wrogość wobec innych oraz chęć dominacji, poczucie górowania nad innymi, a także instrumentalne ich traktowanie. 


\section{BARIERY ŚRODOWISKOWE}

Przedstawione powyżej cechy i postawy wobec krytyki są kształtowane w interakcji z bezpośrednim środowiskiem społecznym tworzących sieć powiązań (rodzina, krewni, grupy rówieśnicze, kręgi towarzyskie), ale także poprzez czynniki skali makrospołecznej: ekonomiczne, technologiczne, ideologiczne, polityczne, społeczne, kulturowe i edukacyjne. Świadomość inhibitorów z tego zakresu może pozwolić w przyszłości omijać wiele ograniczeń i pułapek, a przez to minimalizować ich destrukcyjny wpływ.

\section{Bariery środowiska wychowawczego}

Rodzina i pierwsze kontakty społeczne wyznaczają dziecku zakres autonomii i odpowiedzialności, wpływają na jego stosunek do siebie i innych. To niezwykle ważne środowiska wychowawcze, które nadają kształt formom późniejszego nastawienia wobec krytyki — w ich funkcjonowaniu można szukać źródeł wczesnych barier. Wzajemne relacje, sposób postrzegania i wypełniania ról rodzicielskich (style wychowawcze), poziom bezpieczeństwa oraz stabilności więzi rodzinnych determinują rozwijanie się emocjonalnych i osobowościowych predyspozycji do krytyki. Z kolei kultura domu rodzinnego — formy zaangażowania w życie społeczne, kulturalne, w edukację i wychowanie dziecka; jakość, poziom i sposób komunikacji; zainteresowania i pasje. Światopogląd rodziców może też kształtować nawyki poznawcze dziecka.

Drugim środowiskiem wychowawczym, szczególnie istotnym od okresu średniego i późnego dzieciństwa, są rówieśnicy i koledzy, których zachowania stanowią dla dziecka rodzaj lustra społecznego, modyfikującego ocenę samego siebie i formy ustosunkowań interpersonalnych.

Wśród szczegółowych czynników, negatywnie wpływających na ujawnianie przez dziecko krytycyzmu znaczące są:

- represyjne sposoby wychowywania i socjalizacji w rodzinie (hermetyczność, absolutyzacja oraz rygor norm i wymagań) Zawężając horyzont intelektualnych/społecznych aspiracji, a także negatywnie wpływając na samoocenę, opresyjni rodzice są źródłem pojawienia się u dziecka zgeneralizowanego poczucia niższości i małej wartości, a także niewielkiej skuteczności działań oraz negatywnej oceny własnych osiągnięć, pośrednio kształtując wzory bezkrytycznych lub destruktywnie krytycznych ustosunkowań (takich jak nonkonformizm, pasywność, agresja) wobec wiedzy oraz w stosunku do innych. Generalnie można więc założyć, że inhibitorem konstruktywnego krytycyzmu jest brak doświadczania podmiotowości i negatywne wzorce wynikające ze sposobów wychowawczych. Jak zauważa Robert Linton: 
w społeczeństwach, w których wzory kulturowe nakazują dziecku absolutne posłuszeństwo wobec rodziców jako warunek wstępny otrzymywania jakichkolwiek nagród, normalny osobnik dorosły będzie wykazywał tendencje do uległości, zależności i braku inicjatywy (Linton, 2000: 169).

- rówieśnicze normy promujące konformizm

Działają one wówczas, gdy podtrzymywanie spójności grupy wymaga redukowania indywidualnych praw i autonomii; akcentowania bezwarunkowej lojalności jako najwyższej wartości; a często dyskryminacyjnego, socjocentrycznego mechanizmu różnicowania „my - oni”. Nierzadko wysoką pozycję w takiej grupie uzyskują „cenzorzy poprawności myślenia”, wskazujący i wykluczający z niej nieprawomyślnych.

Bariery społeczne, kulturowe, ideologiczne i polityczne

Stawianie pytań czy dociekanie może wzbudzać niepokój rodziców, a krytyczny namysł często wydaje się niebezpieczny dla edukacji, ale przede wszystkim generuje poczucie zagrożenia społecznych i politycznych ośrodków władzy. W budowaniu społeczeństwa demokratycznego, otwartego na krytykę i dyskusję negatywnie oddziałują:

- fundamentalizm i populizm ideologii, przemoc i opresyjność politycznych norm

Populizm oraz manifestacja politycznej siły i władzy, wykluczająca dyskurs uzasadnień tworzy społeczeństwa „zamknięte”, „monologiczne”, jak nazywał je Józef Tischner (Tischner, 1992), takie, które charakteryzuje: pasywność i bezrefleksyjność, niechęć do krytycznej różnorodności i indywidualizmu; uznawanie narzuconych standardów a priori za poprawne, jedynie właściwe sposoby zachowania; bezrefleksyjne aprobowanie i podążanie za populistycznymi hasłami i ideami (Krastev, 2018).

- irrelewantność wzorców i hipokryzja obyczajów społecznych Moralne i intelektualne zniewolenie i ubezwłasnowolnienie oraz niszczenie krytycznej opinii publicznej, demaskującej nieprawidłowości i wymuszającej samoograniczanie się władzy, implikują w mentalności jednostek przekazywane generacyjnie skutki, nazywane przez Tomasza Szkudlarka (Szkudlarek, 2000a; Szkudlarek, 2000b) ontologią pozoru i epistemologią uniku. Przejawiają się one jako: rozmywanie i erozja normy uczciwości (mentalnej i materialnej), pozorowanie zmian, cynizm, oportunizm oraz skuteczne cwaniactwo. Doprowadzić mogą do uprawomocnienia w potocznym przekonaniu kultu przeciętności wzorów, irrelewantnych norm i antyhumanitarnych ideałów oraz mentalnego podporządkowania. 
- tradycjonalizm, egocentryzm i socjocentryzm społeczeństw W opinii Paula (Paul \& Elder, 2014) realizm postrzegania (i jakość interpretowania) rzeczywistości społeczno-politycznej może zostać zaburzony przez postawy: egocentryzmu (w polityce — kultu jednostki) „tylko ja mam racje”, socjocentryzmu „tylko my mamy rację”, życzeniowości „tak byłoby lepiej”, tradycjonalizmu „tak było zawsze”, egoizmu „dla mnie tak będzie lepiej”. Ważnym czynnikiem regulującym powyższe postawy staje się nieuważność i niewrażliwość na drugiego człowieka, wyrażające się swoistym „deficytem współczucia” (Krastev, 2018: 40) — brakiem tolerancji i otwartości.

- pogląd o małej przydatności krytyki w osiąganiu sukcesu życiowego

W wyniku zakorzenionych nieformalnych zasad społecznych częsta jest aprobata przeświadczenia, że $\mathrm{w}$ zetknięciu z przełożonymi krytyka może przynieść straty, a nie korzyści. W powszechnym rozumieniu osoby krytyczne bywają uznawane za naiwnych idealistów lub nawet prowokatorów, szczególnie w zawodach mających porządek hierarchiczny. Dziecko wychowane w takiej autorytarnej, mało demokratycznej społeczności będzie miało trudności z przyswojeniem sobie zasad krytycznego myślenia, choć oponenci krytyki, aby obronić posiadane prawa i przywileje, argumentują, że prowadzi ona do anarchizacji i destabilizacji życia społecznego, do utraty oparcia w trwałych i kulturowo akceptowanych wartościach.

- pośpiech, szybkość i nietrwałość jako wyznaczniki współczesnego stylu życia

Do tradycyjnych barier krytycyzmu czasy współczesne dodały negatywny wpływ innych procesów, pozostających w związku z rewolucją technologiczną, komunikacyjną i informacyjną. Inhibitorami konstruktywnego krytycyzmu są pośpiech i szybkość, podczas gdy znakiem płynnej, niepewnej i migotliwej (Bauman, 2000; Szkudlarek, 2000a; Szkudlarek, 2000b) współczesnej cywilizacji stał się brak czasu. Jak pisze Adam Zagajewski, „niemodne jest zatrzymanie się pośrodku wiosennej łąki i zamyślenie” (Zagajewski, 2019: 201). Parafrazując poetę, „niemodne” stają się również racjonalność i spokojna refleksja krytyczna. Świat mediów tworzy przestrzeń nieustannej zmiany, powierzchowności, niestałości i prowizoryczności. Wcześniejsze informacje zostają błyskawicznie wypierane, a pamięć tego, co było doświadczane „wczoraj”, przesłonięta zostaje ostrością, świeżością doznań aktualnych, zaś naukowe periodyki, opierające dystrybucję wiedzy na rzetelnej weryfikacji danych i krytycznych recenzjach, nie nadążają za opisem zjawisk i interpretacją transformacji szybko zmieniającej się rzeczywistości. To opóźnienie powoduje, że ich rolę w kształtowaniu opinii publicznej w sposób niekontrolowany przejmują media. 
- chaotyczność i fragmentaryczność informacji oraz dyfuzja odpowiedzialności i celowa dezinformacja

Wiele form medialnej popkultury cechuje obecność fałszywych informacji - faktoidów (Pratkanis \& Aronson, 2003: 93) i fake newsów, które mają dezinformować i wprowadzać zamęt (Lamża, 2020). Wizualna atrakcyjność rzeczywistości medialnej uniemożliwia zachowanie krytycznego dystansu i niezależnego osądu, także dlatego, iż tradycja krytycznego namysłu wypracowana została raczej w kulturze pisma, a nie w alinearnej „postpiśmiennej” kulturze przedstawień (Dukaj, 2019). Druk poprzez analogowy porządek daje przestrzeń na uporządkowanie myśli, zaś media elektroniczne wymuszają natychmiastową reakcję. Specyfiką społeczeństwa sieci jest „bezpośredni transfer przeżyć" (Dukaj, 2019: 226), chaotyczność poznania, przypadkowość i kalejdoskopowość wrażeń. Atrakcyjność owej „bezpośredniej” formy uwodzi, usypiając czujność odbiorcy. Anonimowość mediów (a szczególnie internetu, mediów społecznościowych) powoduje dyfuzję odpowiedzialności za słowo, za jego prawdziwość - wiarygodność, rzetelność przekazywanej informacji. Sądy celebrytów lub polityków stają się równoprawnym źródłem wiedzy, nieraz bardziej nośnymi niż głos profesjonalistów.

- kryzys wiarygodności i nieufność wobec merytokratycznych elit

Opisywany już wcześniej przez socjologów i politologów bunt wobec merytokracji, wobec osób zawdzięczających swój status wykształceniu i wiedzy (Krastev, 2018) potęguje tendencję do bezkrytycznej wiary w proste, nośne idee. Czasy ogólnoświatowej pandemii, w której internet stał się podstawowym (dla niektórych jedynym) źródłem wiedzy unaoczniły i zintensyfikowały te negatywne zjawiska i charakterystyki współczesności. Niezwykle destrukcyjny jest pojawiający się w ostatnich czasach kryzys wiarygodności - atrofia znaczenia autorytetów naukowych, moralnych i twórców, utrata wpływu badaczy na opinię publiczną oraz znaczna hermetyzacja i wyalienowanie środowiska naukowego, wyrażająca się dużą specjalizacją, małą generatywnością odkryć i brakiem przekładalności tychże na praktykę życia (Wasylczyk, 2020). Dewaluację, translokację i dyfuzję roli ekspertów dobrze scharakteryzował Aaron Ciechanover, noblista z dziedziny chemii, stwierdzając:

W erze fake newsów trudno o rzetelne źródła informacji. Dziś o nauce opowiadają nawet politycy. Tymczasem naukowcy mają tendencję do izolowania się, pozostawiając tłumaczenie swojej pracy innym. [...] Możemy słuchać kogokolwiek chcemy, ale powinniśmy mieć narzędzia do oceny wiarygodności informacji (Ciechanover, 2020).

Niestety szczególnie dzieci i młodzież, należący do pokolenia „cyfrowych tubylców”, posiadając instrumentalne, techniczne kompetencje 
wykorzystywania narzędzi i poruszania się w technologicznym świecie, bywają naiwnymi konsumentami skomercjalizowanej fikcji, niezdolnymi do krytycznej analizy celów i skutków przekazu medialnego. Jak pisze Krzysztof Varga:

Wieki złote i srebrne były też wiekami ciemnoty i analfabetyzmu, tak jak dzisiejszy wiek plastiku jest wiekiem głupoty i wtórnego analfabetyzmu: ludzie umieją czytać, ale nie umieją rozumieć (Varga, 2020).

\section{Bariery edukacyjne}

Przepisy dotyczące edukacji definiujące system oświatowy wpływają na praktykę organizacji szkoły, tworząc środowisko, w którym rozwijają się krytyczne lub bezkrytyczne postawy wobec porządku społecznego i wiedzy. Ze specyfiki współczesnej kultury szkoły ${ }^{4}$ wynikają ważne bariery myślenia krytycznego:

- paradygmat „kultury milczenia” (Brookfield, 1995)

To częste zjawisko ukrywania wszelkich porażek, problemów pedagogów, zbywania milczeniem ich potrzeb i zgadzania się na erozję autorytetu tej profesji, jej ekonomiczną i społeczną marginalizację.

- standaryzacja i presja efektywności

Dotyczy zorientowania edukacji na „produkt” - kompetencje (a nie na „proces”, w którym nacisk położony jest na aktywność jednostki w konstruowaniu wiedzy), wzmacnianego wykorzystywaniem jako podstawy oceny osiągnięć ucznia testów, w nieznacznym stopniu uwzględniających operacje związane z myśleniem krytycznym.

- rutynowość metod, nadmiar i jednostronność treści

Wieloletnie badania (Czaja-Chudyba, 2013c) ujawnity, że w polskich szkołach nie uczy się zasad poprawnego i samodzielnego myślenia oraz krytycznego oceniania, a raczej dominuje zasada trzech „R" - rules, rutines, regulations (na przykład często można zauważyć dominację czynności porządkowych nad poznawczymi). I w tym przypadku pośpiech, determinujący sposoby realizacji celów oraz przeładowanie treści w programach, jest czynnikiem negatywnie wpływającym na możliwość stosowania krytycznej refleksji. Niekorzystnie oddziałuje także jednostronny i tendencyjny dobór materiałów edukacyjnych (najczęściej podręczników) i tematów bez związku z zainteresowaniami ucznia i realnymi problemami świata.

${ }^{4}$ Wobec obszaru własnych badań empirycznych oraz zakresu teoretycznych analiz i spostrzeżeń innych badaczy (Klus-Stańska, 2002; Klus-Stańska \& Nowicka, 2014) ograniczam refleksje jedynie do specyfiki polskiej edukacji początku XXI wieku. 
- transmisyjność przekazu - receptywność odbioru Nauczyciele za wszelką cenę unikają problemowych sytuacji, odsuwają je w czasie; zadawane pytania oraz próby argumentowania, uzasadniania swoich racji budzą ich frustrację, a uczeń „kwestionujący nauczycielskie argumenty - jest traktowany jako zarozumiały albo bezczelny" (Nowicka, 2009: 117). Prawie niezauważalne jest poszukiwanie błędów i nieścisłości w przekazie podręcznikowym, a końcowe wnioski z zajęć przyjmują postać bezkrytycznie przyjmowanych, jednoznacznych ocen, a także uproszczonych deklaracji o moralizatorskim charakterze, najczęściej narzucanych lub wymuszanych przez nauczyciela. Równie rzadko stosowane w pracy pedagogicznej jest problematyzowanie. W znacznej części zajęć dominującą strategią jest mechaniczne przepytywanie (wymaganie od uczniów jednej, właściwej odpowiedzi) i intymidacja. Nie można więc odmówić racji pesymistycznej konkluzji Lecha Witkowskiego, że: „w typowym funkcjonowaniu rodziny i szkoły, młodzi ludzie są pozostawieni sami sobie w nabywaniu krytycyzmu [...], co czyni zadanie to dla nich niemal beznadziejnym” (Witkowski, 2007: 182).

Przedstawioną powyżej taksonomię należy opatrzyć autorskim komentarzem. Po pierwsze, nie jest to klasyfikacja rozłączna, bowiem negatywizm wobec krytyki jest zazwyczaj pochodną kumulacji wielu równolegle współwystępujących, nakładających się barier, które poprzez wzajemne powiązania tworzą nierozłączny system, specyficzny dla holistycznie ujmowanej jednostki (por. schemat nr 1). Szczegółowość i rozłączność powyższej klasyfikacji mają jedynie porządkujący walor, w znacznej mierze istotny dla działań edukacyjnych i badawczych. Po drugie, oddziaływanie inhibitorów może mieć w indywidualnych przypadkach różne nasilenie, a te same osoby w jednych sytuacjach mogą być krytyczne, w innych zaś kontekstach łatwo powracać do bardziej użytecznych, bezrefleksyjnych sposobów działania. Wobec korelacyjności owych barier trudno też, przy obecnym stanie badań, pokusić się o ich próbę hierarchizacji. Wreszcie, choć źródłem wskazanych hipotez są wieloletnie badania empiryczne, nie pretendują one do miana w pełni wyczerpujących ani ostatecznych ${ }^{5}$.

\section{JAK ROZWIJAĆ MYŚLENIE KRYTYCZNE? REKOMENDACJE EDUKACYJNE}

Nawyk poznawczej samodzielności i odpowiedzialności argumentacji, debaty i refleksji powinien być rozwijany od najwcześniejszych lat szkolnych. W epoce, której wyznacznikami są „bezznaczeniowośc” wielu propagowanych form

${ }^{5}$ Od kilku lat taksonomia ta jest modyfikowana - dopełniana i dopracowywana w wyniku kolejnych badań i analiz teoretycznych oraz interpretacji pojawiających się zjawisk społecznych (por. m.in. Czaja-Chudyba \& Muchacka, 2016; Czaja-Chudyba, 2020). 
funkcjonowania społecznego (Bauman, 2000), ambiwalencja czy polifonia wartości (Szkudlarek, 2000a; Szkudlarek, 2000b), edukacja odżegnująca się od wspierania umiejętności krytycznego myślenia pozostawia jednostkę zagubioną i samotną. Dlatego lata 70. i 80. XX wieku zaowocowały w krajach anglosaskich powstaniem środowisk zainteresowanych systemowym kształceniem myślenia krytycznego.

Za prekursora uczenia myślenia krytycznego należy uznać Ennisa, ale niezwykle istotną rolę w popularyzacji nauczania myślenia krytycznego odegrał Paul - pomysłodawca znanych, choć nieprzetłumaczonych na język polski, holistycznych propozycji (w tym doskonałych podręczników), promujących „remodelowanie” amerykańskich programów nauczania (Paul et al., 1995; Elder, 2006). Za kolejną osobę niezwykle istotną także dla polskiej praktyki rozwijania myślenia krytycznego można uznać Lipmana, twórcę amerykańskiego Instytutu Myślenia Krytycznego, a przede wszystkim autora wydanego w Polsce programu Filozofia dla dzieci, który propagował wyzwalanie krytycyzmu poprzez debatę we wspólnocie dociekającej (Lipman, 2003; Lipman, 2008).

W Polsce poza nielicznymi przykładami nauka krytycznego myślenia nie ma większych tradycji (w okresie PRL-u narzucano zupełnie inną filozofię edukacji, a krytycyzm nie był dopuszczany do standardów kształcenia ani na poziomie akademickim, ani w szkole). Lata transformacji ustrojowej zaowocowały pierwszymi próbami takiego nauczania, niestety o bardzo ograniczonym zasięgu, co dowodziło niewielkiego zainteresowania na rodzimym gruncie metamorfozą edukacji w kierunku refleksyjno-krytycznym.

W kontekście doświadczeń teoretyków i edukatorów należy zauważyć, iż wspólna im jest myśl o kluczowej roli atmosfery, „kultury” szkoły i nauczyciela - osoby, która rozwijając myślenie krytyczne, sama musi uznawać je za potrzebne i ważne. Należy zaryzykować tezę, że próby zastosowania jakiejkolwiek formy myślenia krytycznego w masowej edukacji będą nieefektywne lub doraźne, jeżeli oprócz rozwijania sprawności technicznych nie podejmie się wysiłków, aby psychicznie oswajać ucznia i nauczyciela z sytuacją krytyki oraz przybliżać im społeczną i cywilizacyjną potrzebę krytycyzmu. Aby przeciwdziałać powstawaniu hermetycznego elitaryzmu, ważne jest też uprzystępnienie, demitologizowanie myślenia krytycznego, traktowanie go jako codziennej umiejętności, w którą wyposażamy każde dziecko i każdego dorosłego.

Podejmując się zadania wspierania krytycyzmu, należy odpowiedzieć także na szereg pytań i dylematów dotyczących definicyjnego (ontologicznego) i metodologicznego (epistemologicznego) statusu zarówno tego pojęcia, jak i procesów kierunkujących metodyczne rozwiązania. To pytania o:

-ogólność vs. dziedzinowość krytycyzmu - a więc o to, czy naukę myślenia krytycznego powinno się traktować jako rozwiązywanie realnych problemów, czy też kształcone mogą być zestawy ogólnych umiejętności rozumowania bez powiązania z treściami przedmiotowymi; 
- poziom zdolności i wiedzy - czy krytycyzm można traktować jako oddzielną cechę/postawę wobec rzeczywistości, czy też jako najwyższy poziom uzdolnień w konkretnej dziedzinie, który może być dostępny jedynie wybitnym znawcom, a także - co pomaga w rozwijaniu zdolności krytycznych — jako duży zasób wiedzy czy też niewiedzę?

- moment rozpoczęcia nauczania - zagadnienie, czy, kiedy i w jakim zakresie można rozpocząć kształcenie myślenia krytycznego u dzieci. Jest to pochodna postpiagetowskiego przekonania, że małemu dziecku brak narzędzi poznawczych (szczególnie umiejętności logiczno-analitycznych) do wyrażania konstruktywnej krytyki i refleksji, a zbyt wczesne wymaganie od niego tak skomplikowanych operacji może przynieść zbyt banalne i trywialne rozwiązania (Arlin, 1990). W świetle doniesień współczesnych badaczy (Matthews, 1996) można przypuszczać, iż dzieci cechują się większymi możliwościami w zakresie myślenia abstrakcyjnego, niż uważał Jean Piaget spontanicznie filozofują, wykazując naturalną ciekawość i zdziwienie, a także są w stanie podjąć refleksję krytyczną dotyczącą na przykład zagadnień moralnych;

— metody oceny i efektywność kształcenia — związane z badaniem skutków nauczania myślenia krytycznego. Dużym problemem jest bowiem zauważalny brak bezpośredniego transferu pomiędzy sztucznie wyćwiczonymi sprawnościami myślenia krytycznego (w warunkach treningów) a rozwiązywaniem konkretnych życiowych problemów. Optymizmem napawa fakt, iż dostępne badania na temat skutków nauczania myślenia krytycznego (na przykład raporty Delphi, Kurfis) wskazują na korzystne efekty w rozumowaniu lub postawach uczestników, jednak potrzeba wielu lat, aby tego typu innowacje zakorzeniły się w dydaktyce i kulturze szkoły;

- prawdziwości uzasadnień - to klasyczne pytanie o jednostronność, relatywizm vs. obiektywność (absolutyzm) prawdy, które implikuje imperatyw sceptycznego kwestionowania i weryfikowania dowodów, a więc pytanie - co i na jakich warunkach uznamy za prawdziwe. Zdając sobie sprawę z nierozstrzygalności tego dylematu również na gruncie filozofii, warto zainspirować się tropem zdroworozsądkowej myśli Umberta Eco, który stwierdza:

chociaż żadne pojedyncze kryterium nie jest w stu procentach zadawalające, zawierzamy zwykle racjonalnym przypuszczeniom opartym na zrównoważonej ocenie wynikającej z różnych metod sprawdzania [...] wszyscy ufamy określonym metodom instynktownym, opartym w zasadniczej mierze na ugodzie społecznej (Eco, 2019: 279-281).

Edukacja krytyczna powinna realizować więc podwójny cel — służyć rozwijaniu zdolności myślenia, a jednocześnie pełnić rolę emancypacyjną. Od najmłodszych lat można rozpocząć 
intuicyjne wspieranie dyspozycji motywacyjnych i osobowych do myślenia krytycznego, będących przejawem owego „ducha krytycyzmu” — postawy krytycznej. Nastawienie to konstytuują cechy uczciwości i sprawiedliwości, będące przejawem etycznego kontekstu krytycyzmu, intensyfikujące wyczulenie na krzywdę, fałsz i zakłamanie. Przedkładają działania moralnie słuszne i prawe ponad własne partykularne korzyści, włączają bezstronność i „nieprzekupność”, często działają „w imię sprawy”. Niezależność, autonomia i odwaga, a niekiedy nawet zaczepność wobec świata (Czerepaniak-Walczak, 2006) będzie wsparciem dla ciekawości i wnikliwości. Te z kolei pomogą w budowaniu postawy „nie jestem pewien” - „sprawdzam” (Garstka \& Śliwerski, 2019), która uruchamia samodzielność myślenia i argumentowania, postawy sceptycyzmu, precyzji i intelektualnej pokory z charakterystycznym „zawieszeniem” pewności, a wreszcie refleksyjność i samoświadomość, dzięki którym możliwe jest odkrywanie problematyczności i kwestionowanie oczywistości, a także skupienie i nadawanie znaczenia własnym myślom, emocjom i doświadczeniom. Podkreślić należy, iż szczególnie małe dzieci winne być w tym procesie wspierane, a nie sterowane (czy trenowane). Będzie to możliwe poprzez oferowanie, stwarzanie okazji, zachęcanie, motywowanie, podkreślanie samodzielności dziecka.

Poniżej przedstawione zostały autorskie rekomendacje, które sformułowano na marginesie opublikowanego abarietycznego programu kształcenia krytycznego myślenia PoWażne Sprawy (Czaja-Chudyba, 2020), nawiązujące do autorskiej strategii „oswajania z krytyką”.

Uczenie konstruktywnego krytycyzmu w szkole podstawowej winno rozpocząć się od przyzwyczajania nauczyciela i uczniów do oczywistości i normalności sytuacji krytyki i stymulowania ich motywacji oraz tworzenia klimatu wspierającego konstruktywny krytycyzm i popularyzowania wśród uczniów wzorca zachowań, który jest związany z krytycznym myśleniem (minimalizacja barier emocjonalno-motywacyjnych i osobowościowych). W dalszej części zajęcia mogą rozwijać krytyczną dyskusję oraz uczyć technik i strategii analityczno-krytycznych (minimalizacja barier poznawczych). Uczniowie rozwijają krytycyzm podczas zajęć problemowych, otwartych na wielość rozwiązań i interpretacji. Czynnikiem wyzwalającym myślenie krytyczne jest uświadomienie sobie przez dzieci konfliktu poznawczego, niespójności pomiędzy dotychczasową wiedzą i sposobami rozwiązania problemu a nowymi wyzwaniami i informacjami. Krytyczna analiza pojęć i informacji, sproblematyzowanych do kontekstu zrozumiałego dla dzieci, może obejmować między innymi: ocenę ich racjonalności (potwierdzenia w empirycznej obserwacji, oceny rzetelności); uświadamianie ich znaczenia i pochodzenia; badanie idei przeciwstawnych; określanie kontekstu ich zastosowań.

Zgodnie z tematyką i celami zajęć w ich realizacji warto przestrzegać poniższych zasad: 
1. ważności ucznia - poważnego traktowania ucznia oraz jego pytań i wypowiedzi; potwierdzania wartości podejmowanych wysiłków, zainteresowań i zdolności;

2. bezpieczeństwa - gwarantowania uczniom poczucia pewności w wymiarze tak indywidualnym, jak i społecznym (minimalizowanie przejawów lekceważenia, rywalizacji, konkurencji i wrogości, grupowego konformizmu i uniformizmu);

3. otwartości na różnorodność - tolerancji wobec inności, rozważania różnych interpretacji; uczenia płynności myślenia;

4. dociekliwości - stawiania pytań, szukania kontrowersji, sprzeczności i paradoksów;

5. precyzyjności - przybliżania problemu za pomocą zrozumiałych pojęć i trafnych kategorii;

6. weryfikacji - sprawdzania wartości, wiarygodności, bezstronności, aktualności, adekwatności i istotności dowodów, argumentów i egzemplifikacji;

7. ostrożności - demaskowania tendencyjności i manipulacji;

8. jasności komunikacji - respektowania reguł dialogu i negocjacji, zachęcania do wspólnych dyskusji i deliberacji;

9. czasu na namysł i refleksję — pozwolenia uczniom myśleć w swoim tempie, bez pospieszania i niecierpliwości;

10. problemowości - akceptowania braku pewności, a także odnajdowania systemowych zależności;

11. poznawczej odpowiedzialności — uzasadniania swoich poglądów, wspierania wypowiedzi wartościowymi argumentami;

12. konstruktywności - wykorzystywania błędów w celu polepszenia myślenia, doskonalenia idei.

Wykorzystanie każdej z tych zasad otwiera furtkę dla tworzenia swoistych pól wolności edukacyjnej, w której konstruktywny krytycyzm prowadzi do brania odpowiedzialności za proces edukacji i autoedukacji. Istotne jest więc, aby podczas dyskusji krytyka: nie była personalna, a dotyczyła idei (argumentów), sposobu myślenia, działania, wytworów; nie była jednostronna i tendencyjna; nie była skrótem (tłumaczyła swoje podstawy, źródła); nie była bezcelowa; nie była narzędziem hierarchizacji (nie służła zdobyciu władzy, przewagi nad krytykowanym).

Jednak kilkunastoletnie doświadczenie praktyki stymulowania myślenia krytycznego u studentów pozwala stwierdzić, że aktywizowanie postawy krytycznej jest zadaniem trudnym. Przede wszystkim wymaga niebagatelnego wysiłku, czasu i zaangażowania nauczyciela oraz uczniów. Jak stwierdza Witkowski: „«wychowanie do niepokoju» wymaga znacznie większej odpowiedzialności, odwagi i wyobraźni pedagogicznej niż zagłaskiwanie" (Witkowski, 2007: 292). Niewielka jest także przekładalność idei promujących krytyczne myślenie na obszar masowej edukacji; nieliczne są propozycje realistycznych 
programów; na przestrzeni kilkudziesięciu lat u twórców ideologii edukacyjnych i polityki oświatowej kolejnych władz państwowych nie było też dostatecznej woli wprowadzania myślenia krytycznego. Nierzadko także proces ten wywołuje u uczniów i nauczycieli skrajne, często negatywne odczucia — opór i zawstydzenie, współwystępujące z pokusą kategorycznego i destruktywnego, a także permanentnego i osobowego krytykanctwa.

\section{ZAKOŃCZENIE}

Konsekwencją przedstawionego w treści artykułu obrazu personalnych, społecznych i politycznych barier w myśleniu krytycznym jest poszerzanie się grupy osób podatnych na manipulację, wierzących w informacje o znikomej lub żadnej wartości, a nawet wiarygodności, a także przekazujących je innym. Coraz tatwiej też za pomocą tych nieracjonalnych wiadomości, generujących rzeczywiste emocje, dokonywać zmian społecznych; ubezwłasnowolniać poznawczo jednostki w „informacyjnych bańkach” narzuconych przekonań, jak również — poprzez sterowanie opinią społeczną i wyborami jednostek - kreować politykę, osoby czy idee. Konstruktywnie krytyczne myślenie i dociekanie mogą stanowić obronę przed takimi przejawami fałszowania/zakłamywania prawdy, a także ignorancji i indoktrynacji. W sferze indywidualnych i społecznych korzyści moga przyczynić się także do doskonalenia umiejętności odczytywania tych tekstów i symboli kultury, które są nieoczywiste lub trudne, wspierania aktywnego badania rzeczywistości, zaufania do naukowo potwierdzonych dowodów, a wreszcie - do zdobywania mądrości. Bowiem należy założyć, iż odpowiedzialność poznawcza i samodzielność myślenia oraz świadomość własnej omylności stanowią niezbywalny element racjonalnej wiedzy i mądrości człowieka. W tym kierunku prowadzi konkluzja Lipmana (Lipman, 1996), który określa krytyczność jako zdobywanie przez jednostkę refleksyjnej, dojrzałej mądrości — swoistą drogę ku mądrości, która, jak słusznie zauważa Henryka Kwiatkowska (Kwiatkowska, 2003) bardziej określana jest przez siłę wątpienia i poznawczo-filozoficznych zapytań niż przez jakość upewnień. W skali globalnej każda próba aplikacji tego procesu do edukacji tworzy takie konteksty nauczania, które mogą uchronić ją przed trywialnością, imposybilizmem i schematyzmem.

\section{BIBLIOGRAFIA}

Arlin, P.K. (1990). Wisdom: the art of problem finding (s. 230-243). W: R. Sternberg (Red.). Wisdom. Its nature, origins, and development. New York: Cambridge University Press.

Bauman, Z. (2000). Globalizacja. Warszawa: Państwowy Instytut Wydawniczy.

Brookfield, S.D. (1995). Becoming a critically reflective teacher. San Francisco: John Willey $\&$ Sons, Inc. 
Czaja-Chudyba, I. (2013a). Kompetencje krytyczne w twórczej refleksji nauczyciela (s. 129155). W: I. Adamek \& J. Bałachowicz (Red.). Kompetencje kreatywne nauczyciela wczesnej edukacji dziecka. Kraków: Oficyna Wydawnicza Impuls.

Czaja-Chudyba, I. (2013b). Krytycyzm - wartością czy antywartością edukacji? (s. 121-129). W: I. Adamek, Z. Szarota, \& E. Żmijewska (Red.). Wartości w teorii i praktyce edukacyjnej. Kraków: Wydawnictwo Naukowe UP.

Czaja-Chudyba, I. (2013c). Myślenie krytyczne w kontekstach edukacji wczesnoszkolnej - uwarunkowania nieobecności. Kraków: Wydawnictwo Naukowe UP.

Czaja-Chudyba, I. (2017). Zagubione wartości - mądrość, krytycyzm i refleksyjność w podręcznikach do edukacji wczesnoszkolnej (s. 12-26). W: I. Czaja-Chudyba, B. Pawlak, \& J. Vaškevič-Buś (Red.) Wizja świata - wizja dziecka w przestrzeni podręczników do edukacji wczesnoszkolnej. Kraków: Wydawnictwo Naukowe UP.

Czaja-Chudyba, I. (2020). Myślenie krytyczne w edukacji. Metodyka ksztatcenia w szkole podstawowej (= Edukacja dla Mądrości). Łódź: Wydawnictwo UŁ.

Czaja-Chudyba, I. \& Muchacka, B. (2016). Nauczyciele wczesnej edukacji (koncepcje, ksztatcenie, wyzwania). Kraków: Petrus.

Czerepaniak-Walczak, M. (1995). Między dostosowaniem a zmianq. Elementy emancypacyjnej teorii edukacji. Szczecin: Wydawnictwo Naukowe US.

Czerepaniak-Walczak, M. (2006). Pedagogika emancypacyjna. Rozwój świadomości krytycznej człowieka. Gdańsk: Gdańskie Wydawnictwo Psychologiczne.

Dennet, D.C. (2017). Od bakterii do Bacha. O ewolucji umystów. (Przeł. K. Bielecka \& M. Mitkowski). Kraków: Copernicus Center.

Dewey, J. (1988). Jak myślimy?. (Przeł. Z. Bastgenówna). Warszawa: Państwowe Wydawnictwo Naukowe.

Dukaj, J. (2019). Po piśmie. Kraków: Wydawnictwo Literackie.

Eco, U. (2019). Na ramionach olbrzymów. Wykłady na festiwalu Milanesia w latach 2001-2015. (Przeł. K. Żaboklicki). Warszawa: Noir Sur Blanc.

Elder, L. (2006). The miniature guide to critical tbinking for cbildren. Santa Rosa: Foundation for Critical Thinking.

Ennis, R.H. (2001). Goals for a critical thinking curriculum and its assessment (s. 44-46). W: A.L. Costa (Red.). Developing minds. A resource book for teaching thinking. Alexandria: Association for Supervision and Curriculum Development.

Ennis, R.H. (2003). Critical thinking assessment (s. 293-313). W: D. Fasco (Red.). Critical thinking and reasoning. Current research, theory, and practice. Cresskill: Hampton Press, Inc.

Garstka, T. \& Śliwerski, A. (2019). Psychopedagogiczne mity (cz. 2: Dlaczego warto pytać o dowody). Warszawa: Wolter Kluwers.

Halpern, D.F. (2003a). The „how” and „why” of critical thinking assessment (s. 355-366). W: D. Fasco (Red.). Critical thinking and reasoning. Current research, theory, and practice. Cresskill: Hampton Press, Inc.

Halpern, D.F. (2003b). Thinking critically about creative thinking (s. 189-207). W: M.A. Runco (Red.). Critical creative processes. Cresskill: Hampton Press, Inc.

Ciechanover, A. (2020). Czy przechodzimy przez kryzys wiedzy? Rola nauki w społeczeństwie. Panel dyskusyjny z A. Cichanoverem, 22.06.2020. Dostęp: https://pap-mediaroom.pl/ ludzie-i-kultura/czy-przechodzimy-kryzys-wiedzy-i-nauki-na-pewno-stoimy-u-progu-duzej-zmiany (26.09.2020).

Klus-Stańska, D. (2002). Konstruowanie wiedzy w szkole. Olsztyn: Wydawnictwo UW-M.

Klus-Stańska, D. \& Nowicka, M. (2014). Sensy i bezsensy edukacji wczesnoszkolnej. Gdańsk: Harmonia Universalis. 
Kohlberg, L. \& Mayer, R. (1990). Rozwój jako cel wychowania. (Przeł. U. Zbroja-Maciejewska). Toruń: Centrum Doskonalenia Nauczycieli im. Wł. Spasowskiego.

Krastev, I. (2018). Co po Europie?. (Przeł. A. Gustowski). Warszawa: Krytyka Polityczna.

Kwaśnica, R. (1990). Ukryte założenia trzech krytyk, przyczynek do samowiedzy pedagogii przejścia i pogranicza (s. 118-157). W: Z. Kwieciński \& L. Witkowski (Red.). Ku pedagogii pogranicza. Toruń: Uniwersytet Mikołaja Kopernika.

Kwaśnica, R. (2007). Dwie racjonalności. Od filozofii sensu ku pedagogice ogólnej. Wrocław: Wydawnictwo Naukowe Dolnośląskiej Szkoły Wyższej Edukacji TWP we Wrocławiu.

Kwiatkowska, H. (2003). Ontologia działania pedagogicznego inspiracją kształcenia nauczycieli (s. 81-90). W: D. Ekiert-Oldroyd (Red.). Problemy wspótczesnej pedeutologii. Teoria praktyka - perspektywy. Katowice: Wydawnictwo UŚ.

Lamża, Ł. (2020). Światy równoległe. Czego ucza nas płaskoziemcy, bomeopaci i różdżkarze?. Wołowiec: Czarne.

Linton, R. (2000). Kulturowe podstawy osobowości. (Przeł. A. Jasińska-Kania). Warszawa: Wydawnictwo Naukowe PWN.

Lipman, M. (1996). Czym jest krytyczne myślenie? (s. 11-20). W: B. Elwich \& A. Łagodzka (Red.). Filozofia dla dzieci. Wybór artykułów. (Przeł. K. Bobiński). Warszawa: Fundacja Edukacja dla Demokracji.

Lipman, M. (2003). Thinking in education. Cambridge: Cambridge University Press.

Lipman, M., Sharp, A.M. \& Oscanyan, F. S. (2008). Filozofia w szkole. (Przeł. B. Elwich \& A. Łagodzka). Warszawa: Centralny Ośrodek Doskonalenia Nauczycieli.

Maruszewski, T. (2001). Psychologia poznania. Sposoby rozumienia siebie i świata (=Wyzwania Nauki). Gdańsk: Gdańskie Wydawnictwo Psychologiczne.

Matthews, G. (1996). Teoria rozwoju poznawczego J. Piageta a filozofowanie dzieci (s. 21-24). (Przeł. B. Pytkowska-Kapulkin). W: B. Elwich \& A. Eagodzka (Red.). Filozofia dla dzieci. Wybór artykutów. Warszawa: Fundacja Edukacja dla Demokracji.

McLaren, P. (1991). Język, struktura społeczna i tworzenie podmiotowości (cz. 1, s. 38-56). W: Z. Kwieciński (Red.). Nieobecne dyskursy. (Przeł. H. Zielińska). Toruń: Wydawnictwo UMK.

Modgil, S. \& Modgil, C. (Red.). (1986). Koblberg: Consensus and controversy. Lewes: Falmer Press.

Nęcka, E., Orzechowski, J., \& Szymura, B. (2006). Psychologia poznawcza. Warszawa: Wydawnictwo Naukowe PWN / Academica Wydawnictwo SWPS.

Nęcka, E., Orzechowski, J., Słabosz, A., \& Szymura, B. (2008). Trening twórczości. Gdańsk: Gdańskie Wydawnictwo Psychologiczne.

Nowicka, M. (2009). Socjalizacja ukryta w procesie dydaktycznym — między wsparciem a hamowaniem rozwoju tożsamości ucznia (s. 109-123). Z inspiracji koncepcją Jürgena Habermasa. W: L. Hurło, D. Klus-Stańska, \& M. Łojko (Red.). Paradygmaty wspótczesnej dydaktyki. Kraków: Oficyna Wydawnicza Impuls.

Obuchowski, K. (1993). Człowiek intencjonalny. Warszawa: Wydawnictwo Naukowe PWN.

Paul, R. (1996). Dwie przeciwstawne teorie wiedzy, uczenia się i wykształcenia: dydaktyczna i krytyczna (s. 3-9). (Przeł. K. Bobiński). W: B. Elwich \& A. Łagodzka (Red.). Filozofia dla dzieci. Wybór artykutów. Warszawa: Fundacja Edukacja dla Demokracji.

Paul, R. \& Elder, L. (2005). The nature and functions of critical \& creative thinking. Dillon Beach: The Foundation for Critical Thinking.

Paul, R. \& Elder, L. (2014). Critical thinking. Tools for taking charge of you professional and personal life. Upper Saddle River: Pearson Education, Inc.

Paul, R., Binker, A.J.A., \& Weil, D. (1995). Critical thinking handbook: K-3rd Grades. Santa Rosa: Foundation for Critical Thinking. 
Piaget, J. (1967). Rozwój ocen moralnych dziecka. (Przeł. T. Kołakowska). Warszawa: Państwowe Wydawnictwo Naukowe.

Pratkanis, A. \& Aronson, E. (2003). Wiek propagandy. Używanie i nadużywanie perswazji na co dzień. (Przeł. J. Radzicki \& M. Szuster). Warszawa: Wydawnictwo Naukowe PWN.

Siegel, H. (2019). Myślenie krytyczne i indoktrynacja. (Przeł. P. Kostyło \& K. Nowak). Bydgoszcz: Wydawnictwo Uniwersytetu Kazimierza Wielkiego.

Socha, P. (2000). Stadialny rozwój sądów moralnych w koncepcji Lawrence’a Kohlberga. Przegląd i ocena głównych tez (s. 145-164). W: P. Socha (Red.). Duchowy rozwój człowieka: osobowość, wiara, religijność. Stadialne koncepcje rozwoju w ciagu życia. Kraków: Wydawnictwo UJ.

Szkudlarek, T. (2000a). Wyzwanie pedagogiki krytycznej (s. 11-48). W: T. Szkudlarek \& B. Śliwerski (Red.). Wyzwania pedagogiki krytycznej i antypedagogiki. Kraków: Oficyna Wydawnicza Impuls.

Szkudlarek, T. (2000b). Wyzwanie „trzeciego paradygmatu” dylematy konstrukcji i dekonstrukcji teorii pedagogicznych (s. 97-111). W: Z. Kwieciński (Red.). Alternatywy myślenia oldla edukacji. Warszawa: IBE.

Tischner, J. (1992). Etyka solidarności oraz Homo sovieticus. Kraków: Znak.

Varga, K. (2020). Wielki pisarz pełen uprzedzeń, także rasowych. Najpewniej bał się „końca cywilizacji białego człowieka". Gazeta Wyborcza, 30.06. Dostęp: https://wyborcza.pl/ ksiazki/7,154165,26074088,warto-jesc-rano-tarta-marchewke-a-konwicki-na-to.html (17.08.2020).

Wasilewska-Kamińska, E. (2016). Myślenie krytyczne jako cel kształcenia. Na przykładzie systemów edukacyjnych USA i Kanady. Warszawa: Wydawnictwo UW.

Wasylczyk, P. (2020). Laser i rezonans magnetyczny były być może ostatnimi ważnymi wynalazkami służącymi ludzkości. Gazeta Wyborcza, 26.09. Dostęp: https://wyborcza.pl/Jutr onauci/7,165057,26338493,laser-i-rezonans-magnetyczny-byly-byc-moze-ostatnimi.html (26.09.2020).

Witkowski, L. (2007). Edukacja i bumanistyka. Nowe (kon)teksty dla nowoczesnycb nauczycieli (t. 2). Warszawa: IBE.

Zagajewski, A. (2019). Substancja nieuporzadkowana. Kraków: Znak. 